\author{
Professional Medical College of Municipal Institution of Higher Education \\ "Rivne Medical Academy” of Rivne Region Council
}

\title{
ANALYSIS OF THE RESULTS OF STUDYING VOCATIONAL TRAINING OF FUTURE JUNIOR SPECIALISTS IN NURSING IN COLLEGES
}

М. Р. Демянчук

Фаховий медичний коледж комунального закладу вищої освіти «Рівненська медична академія» Рівненської обласної ради

\section{АНАЛІЗ РЕЗУЛЬТАТІВ ДОСЛІДЖЕННЯ ПРОФЕСІЙНОЇ ПІДГОТОВКИ МАЙБУТНІХ МОЛОДШИХ СПЕЦІАЛІСТІВ СЕСТРИНСЬКОЇ СПРАВИ У КОЛЕДЖАХ}

\begin{abstract}
The article reproduces the results of theoretical analysis of scientific studies which have been conducted to improve various aspects of vocational training of future junior specialists in nursing. The expediency of conducting a scientific and research work in the process of students' study in medical colleges. It has been generalized that scholars studied problems of formation of professional competence, identity, readiness to different types of activities (research, project, promotion and implementation of healthy lifestyle ideas) in students of medical colleges.

It has been argued that in order to prove the effectiveness of the author's methodic of vocational training of future junior specialists in nursing in medical colleges is necessary to organize experimental research and make analysis of its results. Comparative analysis of results at different stages of the scientific and research work contributed to establishing the effectiveness of the author's methodic for organizing educational process.

The methods of questionnaire, testing, interviewing, observation, evaluation of students' participation in solving professional-situational and simulation problems, etc. have been used to examine readiness of medical colleges students to professional work. In order to determine the formation of students' motives and valuable orientations, to establish the level of knowledge, practical abilities, skills, readiness to professional development at all stages of research students from seven medical colleges have been involved.

The structure of readiness to professional activity of future junior specialists in nursing is presented. The results of the incoming and final controls to determine the levels of formation of all four components and readiness to professional work of students from control and experimental groups in general have been compared. The results of comparative analysis have stated that organization of training of students from experimental groups led to better results in vocational training of future junior specialists in nursing than in the case of traditional training in control groups.
\end{abstract}

Key words: vocational training; medical college; students; nursing; experiment; analysis; results of studying.

Анотація. У статті відтворено результати теоретичного аналізу наукових досліджень, які проводилися з метою вдосконалення різних аспектів професійної підготовки майбутніх молодших спеціалістів сестринської справи. Актуалізовано доцільність проведення науково-дослідної роботи в процесі навчання студентів у медичних коледжах. Узагальнено, що науковці досліджували проблеми формування у студентів медичних коледжів професійної компетентності, ідентичності, готовності до різних видів діяльності: дослідницької, проектної, пропаганди і реалізації ідей здорового способу життя.

Аргументовано, що з метою доведення результативності авторської методики професійної підготовки майбутніх молодших спеціалістів сестринської справи в медичних коледжах необхідно організувати експериментальне дослідження та провести аналіз його результатів. Порівняльний аналіз результатів на різних етапах науково-дослідної роботи сприяв встановленню дієвості авторської методики організації освітнього процесу.

Для діагностування готовності студентів медичних коледжів до роботи за фахом використовувалися методи анкетування, тестування, опитування, спостереження, оцінювання участі студентів у вирішенні професійно-ситуативних і симуляційних завдань та ін. 3 метою визначення сформованості мотивів і ціннісних орієнтацій студентів, встановлення рівня знань, практичних умінь, навичок, готовності до професійного зростання на всіх етапах дослідження задіяно студентів із семи медичних коледжів.

Представлено структуру готовності до професійної діяльності майбутніх молодших спеціалістів сестринської справи. Порівнювалися результати вхідного та підсумкового контролю на предмет встановлення рівнів сформованості всіх чотирьох компонентів і загалом готовності до роботи за фахом студентів контрольних та експериментальних груп. Результати порівняльного аналізу

(C) M. R. Demianchuk 


\section{Materials of International Scientific and Practical Conference \\ “PROFESSIONAL AND COMMUNICATION CULTURE OF THE FUTURE DOCTOR: LINGUISTIC, PEDAGOGICAL AND PHILOSOPHICAL ASPECTS”}

засвідчили, що організація навчання студентів експериментальних груп привела до отримання кращих результатів у професійній підготовці майбутніх молодших спеціалістів сестринської справи, ніж за умов традиційного навчання в контрольних групах.

Ключові слова: професійна підготовка; медичний коледж; студенти; сестринська справа; експеримент; аналіз; результати дослідження.

Introduction. Reforming the medical sector in Ukraine is accompanied by dynamic changes in various fields. Reforms attach both the organization of medical specialists' practical activity and study of future doctors and nursing staff in medical institutions of higher education. Junior specialists in nursing, who are educated in medical colleges, play an important role in the provision of medical care. That is why scholars propose author's methods and technologies of students study in order to improve vocational training of future nurses. Testing of the author's experimental and research works allows checking the effectiveness of the updated organization of study of future junior specialists in nursing. In this way, new scientific approaches and research strategies are implemented in the educational environment of medical colleges.

The aim - analysis of the results of experimental study of vocational training of future junior specialists in nursing in medical colleges.

Methods. Methods of analysis of scientific literary sources have been used for writing the scientific article. This allowed establishing the following:

- researchers prove the expediency of conducting scientific and research work in the process of training of junior medical specialists [3];

- organization of scientific studies in nursing (including vocational training of future specialists in nursing) will contribute to improving nursing care [5];

- medical college is the educational environment of professional development and identity of future specialists in nursing [10] etc.

Comparative analysis of scientific studies gives an opportunity to generalize that researchers create experimental educational environment in medical colleges to determine the directions of modernization of vocational training of future junior specialists in nursing.

Comparative analysis of directions of scientific studies have given a possibility to set educational reserves in vocational training of nursing staff, depending on the defined goals: formation in medical college students of readiness to promoting and implementing healthy lifestyle ideas in future professional activities [1]; formation of research abilities and skills of medical college students in the process of project activities [2]; formation of professional competence of future bachelors of nursing in the process of studying chemical and biological disciplines [4] and natural sciences in medical college [9]; formation of professionally significant qualities of future junior specialists in nursing in the process of vocational training [6]; formation of the bases of professionalism of future nurses in the process of vocational training [7]; formation of professional identity of future junior specialists in nursing on the basis of the deontological approach [8] etc.

Results. In order to analyze the results of experimental study of vocational training of future junior specialists in nursing in medical colleges, determining students' readiness to professional activities has been conducted. Such diagnostics at different stages of scientific and research work gives an opportunity to establish the effectiveness of traditional teaching and the author's methods of organizing the educational process.

Methods of questionnaire, testing, interviewing, observation, evaluating students' participation in deciding professionally-situational and simulation tasks, etc. have been used for diagnosing the readiness of students from medical colleges to professional work. In order to determine the formation of students' motives and valuable orientations, to establish the level of knowledge, practical abilities, skills, readiness to professional development at all stages of research students from seven medical colleges have been involved: Professional Medical College of Municipal Institution of Higher Education "Rivne Medical Academy" of Rivne Region Council; Chernihiv Basic Medical College of Chernihiv Region Council; Zakarpattia Basic State Medical College; Kherson Basic Medical College of Kherson Region Council; Lutsk Basic Medical College; Arsen Richynskyi Kremenets Medical College; Municipal Institution of Higher Education "Novohrad-Volynsk Medical College" of Zhytomyr Region Council.

At the initial stage, the results of diagnostics of the status of medical college graduates' readiness have been analyzed, which make it possible to identify the need to improve vocational training of future junior specialists in nursing in the following areas:

- purposefully form students' motives and value orientations in the context of professional development and growth; such education of strategy will promote the 
acquisition of professional competence by students in the process of study in medical college and professional self-improvement of future nurses during the whole professional activity;

- use of interdisciplinary integration in studying theoretical disciplines and practical activities of students both at the classes (through the use of professionally-oriented interactive, problem-based, situational, simulation tasks), and while practicing in healthcare establishments.
It has been taken into account that identification of participants in the forming stage of the experimental study in different medical colleges and their division into control (CG) and experimental groups (EG) will make it possible to compare the results of traditional training with the updated methods of vocational training of future junior specialists in nursing. For this purpose, the criterion-component composition and indicators of readiness of medical colleges' graduates to professional work have been specified (Table 1).

Table 1. Structure of readiness of future junior specialists in nursing

\begin{tabular}{|l|l|l|}
\hline \multicolumn{1}{|c|}{ Components } & \multicolumn{1}{|c|}{ Criteria } & \multicolumn{1}{c|}{ Indicators } \\
\hline $\begin{array}{l}\text { Motivational- } \\
\text { valuable }\end{array}$ & $\begin{array}{l}\text { Motivational- } \\
\text { axiological }\end{array}$ & $\begin{array}{l}\text { - motivation for professional development in the process of study and } \\
\text { personal growth in professional work; } \\
\text { - awareness of the need for a high level of professional competence as a } \\
\text { topical value at the modern stage of health care sphere development; } \\
\text { - interest in comprehensive vocational training in medical college } \\
\text { corresponding to modern requirements for junior specialists in nursing }\end{array}$ \\
\hline $\begin{array}{l}\text { Theoretical- } \\
\text { cognitive }\end{array}$ & Knowledgeable & $\begin{array}{l}\text { - knowledge in the professional disciplines; } \\
\text { - knowledge in the specific of nursing staff interaction at different levels of } \\
\text { professional relationships; } \\
\text { - theoretical preparedness of students to professional communication }\end{array}$ \\
\hline Practical- & $\begin{array}{l}\text { Praxeological- } \\
\text { active }\end{array}$ & $\begin{array}{l}\text { - ability to use knowledge of professional disciplines in the process of } \\
\text { doing manipulative actions in quasi-professional situations; } \\
\text { - ability to organize optimal professional interaction in simulated } \\
\text { situations; } \\
\text { - ability to integrate results of vocational; training in medical college in } \\
\text { practice }\end{array}$ \\
\hline $\begin{array}{l}\text { Personal- } \\
\text { developmental }\end{array}$ & $\begin{array}{l}\text { Personal- } \\
\text { acmeological }\end{array}$ & $\begin{array}{l}\text { landmarks (acme) of professional growth; } \\
- \text { effectiveness of self-educational activities; } \\
\text { - spreading a professional outlook in the process of getting acquainted } \\
\text { with current tendencies in the development of nursing }\end{array}$ \\
\hline
\end{tabular}

In order of quantitative displaying the formation of all components of readiness of future junior specialists in nursing to professional activities, the basis of which is professional competence, four levels were used: high, sufficient, satisfactory and low. Since the quantitative indicators received at the stage of incoming control in CG and EG have been almost the same, we may confirm that the results obtained can testify to the effectiveness of the author's methodic of vocational training of future junior specialists in nursing in medical colleges.

The basis of author's methodic was realization of such pedagogical conditions:

- creation of motivational-valuable professionally oriented educational environment in medical college;

- direction of competence approach to providing interdisciplinary and integrative theoretical training;
- convergence of interactive, problem and simulation study in praxeological training of future junior specialists in nursing;

- formation of professional identity in professionally mobile future junior specialists in nursing.

Processing and analysis of results have proved a significant growing students' number from experimental groups, which are characterized by a high and sufficient level of professional readiness, and decreasing number of students with satisfactory and low levels. In control groups there has been also a slight positive dynamic that we clarify by the natural influence of education of students in medical colleges.

In order to prove the effectiveness of author's methodic of vocational training of future junior specialists in nursing in medical colleges the statistical data that testified to the readiness of students from CG 


\section{Materials of International Scientific and Practical Conference \\ “PROFESSIONAL AND COMMUNICATION CULTURE OF THE FUTURE DOCTOR: LINGUISTIC, PEDAGOGICAL AND PHILOSOPHICAL ASPECTS”}

and EG to professional work at the stage of incoming and final control have been compared. Such statistical materials are the following:

- number of students, who have shown a certain level of formation of each component and overall readiness to work in specialty; for this purpose, each level is given a numerical expression in points: high 5 points; sufficient -4 points; satisfactory -3 points; low - 2 points;

- calculation of average indicator (AI) of formation of each component and overall readiness to professional activities of junior specialists in nursing from CG and EG.

The results of comparative analysis have testified that organization of training of experimental groups students lead to obtaining better results in vocational training of future junior specialists in nursing than according to traditional training in control groups. Thus, the CG students have observed an increase in the average indicator of formation of all components of the studied readiness by $0.2-0.3$ points, in the EG - by $0.5-0.7$ points, which is by $0.3-0.4$ points better than in students, who have studied according to traditional methods. The reliability of the obtained results testifies use of methods of mathematical

\section{List of literature}

1. Бабаліч В. А. Формування у студентів медичного коледжу готовності до пропаганди і реалізації ідей здорового способу життя у майбутній професійній діяльності : автореф. дис. на здобуття наук. ступеня канд. пед. наук / В. А. Бабаліч. - Кіровоград, 2006. - 20 с.

2. Бабенко Т. П. Формування дослідницьких умінь i навичок студентів медичного коледжу у процесі проектної діяльності : автореф. дис. на здобуття наук. ступеня канд. пед. наук / Т. П. Бабенко. - К., 2015. - 20 с.

3. Біленька Н. В. Організація та проведення науководослідної роботи у системі підготовки молодших медичних спеціалістів / Н. В. Біленька, О. Ю. Крикус // Магістр медсестринства. - 2018. - № 1 (19). - С. 7-10.

4. Борисюк Л. О. Формування професійної компетентності майбутніх бакалаврів сестринської справи у процесі вивчення хіміко-біологічних дисциплін : автореф. дис. на здобуття наук. ступеня канд. пед. наук / Л. О. Борисюк. - Хмельницький, 2016. - 20 с.

5. Губенко І. Я. Розвиток наукових досліджень в медсестринстві як основа вдосконалення медсестринської допомоги / І. Я. Губенко, Л. П. Бразолій, А. Т. Шевченко // Магістр медсестринства. - 2008. - № 1. - С. 28-30.

6. Данюк М. I. Формування професійно значущих якостей майбутніх молодших спеціалістів сестринської processing of statistical materials (by calculating the Fisher criterion). The determined criterion is widely used for the analysis of results in pedagogical studies.

Conclusions and Prospects for Research. Theoretical analysis of scientific studies testifies the relevance of updating the educational environment in which the professional development of junior specialists in nursing takes place. Carrying out the research and experimental work on the basis of several medical colleges of Ukraine through the introduction of the author's experimental system have given the opportunity to determine readiness to professional activities of future junior specialists in nursing.

Analysis of the results of research verifies the expediency of updating the educational environment in medical colleges on the basis of realization of certain pedagogical conditions and use of author's educational and methodological support for vocational training of future junior specialists in nursing.

We see the prospects of further researches in the development of methodical recommendations for medical colleges' lecturers that will present tested educational and methodological materials for improving practice in vocational training of future junior specialists in nursing.

справи в процесі фахової підготовки : дис. ... канд. пед. наук: 13.00.04 / М. І. Данюк. - Тернопіль, 2016. - 309 с.

7. Закусилова Т. О. Формування основ професіоналізму майбутніх медичних сестер у процесі фахової підготовки : автореф. дис. на здобуття наук. ступеня канд. пед. наук / Т. О. Закусилова. - Запоріжжя, 2018. - 20 с.

8. Козак X. I. Формування професійної ідентичності майбутніх молодших спеціалістів сестринської справи на засадах деонтологічного підходу : дис. ... канд. пед. наук: 13.00.04 / Х. І. Козак. - Хмельницький, 2019. 259 c.

9. Комарова Ж. В. Формирование профессиональной компетентности будущей медицинской сестры при освоении естественнонаучных дисциплин в колледже : автореф. дисс. на соискание ученой степени канд. пед. наук / Ж. В. Комарова. - Челябинск, 2012. - 20 с.

10. Мельничук I. М. Медичний коледж як освітнє середовище формування професійної ідентичності майбутніх спеціалістів сестринської справи / I. М. Мельничук, X. I. Козак // Наукові записки Рівненського державного гуманітарного університету. - 2017. - Вип. 16 (59). С. 212-216. 


\section{Materials of International Scientific and Practical Conference \\ "PROFESSIONAL AND COMMUNICATION CULTURE OF THE FUTURE DOCTOR: LINGUISTIC, PEDAGOGICAL AND PHILOSOPHICAL ASPECTS”}

\section{References}

1. Babalich, V.A. (2006). Formuvannia u studentiv medychnoho koledzhu hotovnosti do propahandy i realizatsii idei zdorovoho sposobu zhyttia u maibutnii profesiinii diialnosti [Formation of medical college students' readiness for propaganda and implementation of healthy lifestyle ideas in the future professional activity]. Extended abstract of Candidate's thesis. Kirovohrad [in Ukrainian].

2. Babenko, T.P. (2015). Formuvannia doslidnytskykh umin i navychok studentiv medychnoho koledzhu u protsesi proektnoi diialnosti [Formation of research abilities and skills in medical college students in the process of project activity]. Extended abstract of Candidate's thesis. Kyiv [in Ukrainian].

3. Bilenka, N.V., \& Krukus, O.Yu. (2018). Orhanizatsiia ta provedennia naukovo-doslidnoi roboty u systemi pidhotovky molodshykh medychnykh spetsialistiv [Organizing and conducting scientific and research work in the system of training of junior medical specialists]. Mahistr medsestrynstva-Master of Nursing, 1 (19), 7-10 [in Ukrainian].

4. Borysiuk, L.O. (2016). Formuvannia profesiinoi kompetentnosti maibutnikh bakalavriv sestrynskoi spravy u protsesi vyvchennia khimiko-biolohichnykh dystsyplin [Formation of professional competence of future bachelors in nursing in the course of studying chemical and biological disciplines]. Extended abstract of Candidate's thesis. Khmelnytskyi [in Ukrainian].

5. Hubenko, I.Ya., Brazolii, L.P., \& Shevchenko, A.T. (2008). Rozvytok naukovykh doslidzhen v medsestrynstvi yak osnova vdoskonalennia medsestrynskoi dopomohy [Development of scientific studies in nursing as a basis of improving nursing care]. Mahistr medsestrynstva-Master of Nursing, 1, 28-30 [in Ukrainian].
6. Daniuk, M. I. (2016). Formuvannia profesiino znachushchykh yakostei maibutnikh molodshykh spetsialistiv sestrynskoi spravy v protsesi fakhovoi pidhotovky [Formation of professionally significant qualities of future junior specialists in nursing in the process of vocational training]. Candidate's thesis. Ternopil [in Ukrainian].

7. Zakusylova, T.O. (2018). Formuvannia osnov profesionalizmu maibutnikh medychnykh sester u protsesi fakhovoi pidhotovky [Formation of foundations of professionalism of future nurses in the process of vocational training]. Extended abstract of Candidate's thesis. Zaporizhzhia [in Ukrainian].

8. Kozak, Kh.I. (2019). Formuvannia profesiinoi identychnosti maibutnikh molodshykh spetsialistiv sestrynskoi spravy na zasadakh deontolohichnoho pidkhodu [Formation of professional identity of future junior specialists in nursing on the basis of deontological approach]. Candidate's thesis. Khmelnytskyi [in Ukrainian].

9. Komarova, Zh.V. (2012). Formirovanie professionalnoy kompetentnosti budushchey meditsinskoy sestry pri osvoenii estestvenno nauchnykh distsiplin v kolledzhe [Formation of professional competence of future nurse in mastering natural science disciplines in college]. Extended abstract of Candidate's thesis. Chelyabinsk [in Russian].

10. Melnychuk, I.M., \& Kozak, Kh. I. (2017). Medychnyi koledzh yak osvitnie seredovyshche formuvannia profesiinoi identychnosti maibutnikh spetsialistiv sestrynskoi spravy [Medical college as educational environment for formation of professional identity of future specialists in nursing]. Naukovi zapysky Rivnenskoho derzhavnoho humanitarnoho universytetu - Scientific Issues of Rivne State University of Humanities, 16 (59), 212-216 [in Ukrainian]. 